KS. WOJCIECH NECEL SCHR

Wydział Prawa Kanonicznego

Uniwersytetu Kardynała Stefana Wyszyńskiego w Warszawie

\title{
PRZYJECCIE CHRYSTUSA W UCHODŹCACH I PRZESIEDLONYCH. WYTYCZNE PASTORALNO-KANONICZNE
}

Treść: Wprowadzenie. - 1. Motyw wypracowania instrukcji Przyjęcie Chrystusa. - 2. Struktura instrukcji i zawartość poszczególnych części. 3. Wskazania pastoralno-kanoniczne instrukcji. - 3.1. Otwartość na przybyłych warunkiem godnego przyjęcia. - 3.2. Konieczność duszpasterskich rozwiązań. - 3.3. Odpowiedzialność za duszpasterstwo uchodźców i wypędzonych. - 3.4. Obecność wiernych świeckich w pastoralnej posłudze uchodźcom i przymusowo przesiedlonym. - 3.5. Konieczność współpracy z Kościołem a quo uchodźców i wypędzonych. - Zakończenie.

\section{Wprowadzenie}

Ze względu na dynamikę zjawiska współczesnych migracji wciąż na nowo konieczna jest aktualizacja zadań duszpasterskich wobec różnych kategorii migrantów oraz określanie zakresu odpowiedzialności poszczególnych struktur i instytucji kościelnych oraz poszczególnych wiernych. Na fundamencie instrukcji Erga migrantes caritas Christi z 2004 r. ${ }^{1}$, duszpasterska sytuacja uchodźców i wypędzonych wymagała nowych analiz i zdefiniowania specyfiki ich obecności w Kościele Powszechnym, w Kościołach diecezjalnych oraz we wspólnocie parafialnej. Niepokoje polityczne i społeczne w pierwszych dwóch

\footnotetext{
${ }^{1}$ Papieska Rada ds. Duszpasterstwa Migrantów i Podróżujących, Instrukcja Erga migrantes caritas Christi (dalej EMCC), Lublin 2008.
} 
dekadach XXI wieku były swoistym katalizatorem wypracowania przez Papieską Radę ds. Duszpasterstwa Migrantów i Podróżujących wspólnie z Papieską Radą Cor Unum instrukcji: Przyjęcie Chrystusa w uchodźcach i przymusowo wypędzonych ${ }^{2}$.

\section{Motyw wypracowania instrukcji Przyjęcie Chrystusa}

W zamyśle autorów omawiany dokument ma charakter instrukcji ${ }^{3}$. Jest efektem ewolucji wskazań zawartych w wytycznych zatytułowanych: Problem uchodźców. Wyzwanie do solidarności z 1992 roku oraz „owocem teologicznych i pastoralnych przemyśleń, które stały się podstawą do uznania migracji jako pola misyjnego Kościoła, gdzie konieczne jest dawanie świadectwa Dobrej Nowiny o Chrystusie"4. Rzeczywistość uchodźców i wypędzonych jest szczególnym „obszarem, na którym zadaniem Kościoła jest ukazywać i głosić w Jezusie Chrystusie sens miłości Boga do każdego człowieka"s. Ostatecznie „Kościół nie może zaniedbać posługi miłości, tak jak nie może zaniedbać Sakramentów i Słowa"6.

Dla Papieskiej Rady ds. Duszpasterstwa Migrantów i Podróżujących oraz Papieskiej Rady Cor Unum w omawianej instrukcji kluczowym problemem jest poszukiwanie pragmatycznej odpowiedzi na pytanie, w jaki sposób „Kościół może autentycznie wyrażać swoją miłość, gościnne przyjęcie i duszpasterskie zaangażowanie" wobec każdego z uchodźców i wypędzonego"7. W odpowiedzi trzeba zauważyć, że Kościół nie tylko w przeszłości pomagał różnym grupom tworzącym fenomen „ludzi w drodze”, ale również dzisiaj wspiera

\footnotetext{
${ }^{2}$ Papieska Rada ds. Duszpasterstwa Migrantów i Podróżujących, PapieSKa Rada Cor Unum, Instrukcja Przyjęcie Chrystusa w uchodźcach i przymusowo wypędzonych (dalej Przyjęcie Chrystusa), Watykan 2013.

${ }^{3}$ Kodeks Prawa Kanonicznego (dalej KPK), kan. 34 par. 1.

${ }^{4}$ Przyjęcie Chrystusa, Prezentacja dokumentu, s. 5.

${ }^{5}$ TAMżE.

${ }^{6}$ Benedy KT XVI, Encyklika Deus caritas est (dalej DCE), nr 22.

${ }^{7}$ Przyjęcie Chrystusa, art. 106.

${ }^{8}$ Por. Pius XII, Konstytucja Exsul Familia, cz. I; W. Necel, Prawo migranta do specjalnego duszpasterstwa, Warszawa 2012, s. 25-73.
} 
konieczną i wieloraką pomocą poszczególne kategorie migrantów, w tym uchodźców i wysiedlonych. „Liczne interwencje Kościoła mają na celu stworzenie uchodźcom, wysiedleńcom i ofiarom handlu ludźmi odpowiednich możliwości do zachowania ludzkiej godności poprzez zapewnienie im pracy oraz pomocy w przyjęciu praw i obowiązków kraju udzielającego schronienia”9 „Wszystkim tym osobom należy zapewnić regularną pomoc, stworzyć rzetelne możliwości przejścia procesu migracji i zapewnić im korzystanie z podstawowych praw niezbędnych do życia wolnego, godnego i samodzielnego, tak by byli zdolni do budowania «na nowo» swojego życia w innym społeczeństwie"10.

Motywem wypracowania przez Papieską Radę ds. Duszpasterstwa Migrantów i Podróżujących oraz Papieską Radę Cor Unum nowego dokumentu dotyczącego wygnańców i przymusowo przesiedlonych jest potrzeba kształtowania świadomości wspólnoty Kościoła ad quem tak, by otwarła się i przyjęła poszczególnych przybyszów oraz ich małżonków i dzieci. W procesie przyjmowania wygnańców i przesiedlonych konieczne jest wypracowanie pierwszych kroków skierowanych w stronę przybyłych. Zdaniem autorów omawianej instrukcji, na samym początku procesu przyjmowania uchodźców i przymusowo przesiedlonych chodzi przede wszystkim o „okazanie im współczucia i sprawiedliwe traktowanie, które dają tym osobom nadzieję na przyszłość"11.

Kolejnym motywem wypracowania instrukcji Przyjęcie Chrystusa była niewątpliwie potrzeba wskazania na konieczność prowadzenia badań i poszukiwanie nowych rozwiązań apostolatu migracyjnego, „by bronić godności wszystkich, którzy zostali zmuszeni do opuszczenia swoich domów"12 oraz łącząca się z tym dalsza specyfikacja migrujących. W dokumencie autorzy instrukcji wyróżnili expressis verbis nowe kategorie wewnątrz kategorii migrantów, jaką tworzą

\footnotetext{
${ }^{9}$ Przyjęcie Chrystusa. Prezentacja dokumentu, s. 5.

${ }^{10}$ TAMżE.

${ }^{11}$ TAMŻE, s. 6.

12 TAMŻE.
} 
uchodźcy i przesiedleni. Wymienia się między innymi bezpaństwowców, przymusowo przesiedlonych i przymusowo przesiedlonych wewnątrz rodzimych wspólnot państwowych lub etnicznych, ofiary handlu ludźmi, w tym kobiety i dzieci, oraz osoby przemycane przez granice wbrew własnej woli. W dalszej części instrukcji wskazane są szczegółowo prawa „bezpaństwowców” w art. 70, prawa ofiar handlu ludźmi w art. 71-72, prawa ofiar wykorzystanych seksualnie z racji migracji kobiet i dzieci w art. 73, prawa ofiar pracy przymusowej w art. 74 oraz prawa „dzieci - żołnierzy” w art. 75.

\section{Struktura instrukcji i zawartość poszczególnych części}

Instrukcja Przyjęcie Chrystusa w uchodźcach i przymusowo wypę$d z o n y c h$ dzieli się na cztery części. Całość poprzedzona jest Prezentacja dokumentu oraz Wprowadzeniem, składającym się z pierwszych siedmiu artykułów nieposiadających odrębnego tytułu. Artykuły od 8 do 14 są uszeregowane w części I pod tytułem: Misja Kościoła względem uchodźców i innych przymusowo wysiedlonych. Wskazane tu pryncypia ${ }^{13}$ prowadzą do sedna tajemnicy sakramentu przybysza - do Chrystusa obecnego w uchodźcach i innych przymusowo przesiedlonych (art. 13-14). Część ta kończy się apelem zaczerpniętym z nauczania Jana Pawła II, skierowanym do działaczy katolickich: „Chciałbym was zaprosić do pogłębienia świadomości Waszej misji: dostrzegać Chrystusa w każdym bracie i siostrze w potrzebie, głosić i bronić godności każdego migranta, każdego przesiedleńca i każdego uchodźcy. W ten sposób pomoc, którą otrzymują, nie będzie uważana za jałmużnę wypływającą z dobroci serca, ale za akt sprawiedliwości względem nich"14.

Kolejne cztery części konsekwentnie normują i aktywizują działania Kościoła Powszechnego, a także Kościoła diecezjalnego i wspólnoty parafialnej na rzecz obcych. Pierwsza z nich, zatytułowana:

\footnotetext{
${ }^{13}$ Takie jak: znak miłości; ludzkość; rodzinność; tworzenie Mistycznego Ciała Chrystusa; jeden Chleb, jedno Ciało.

${ }^{14}$ Jan PAwe II, Przemówienie do uczestników Zgromadzenia Międzynarodowej Katolickiej Komisji ds. Migracji z 12.11.2001.
} 
Misja Kościoła na rzecz przymusowo przesiedlonych (art. 15-37), wskazuje na Ewangelię jako na źródło podstawowej wieloaspektowej troski o przybyszów. Wśród zasad opieki Kościoła nad uchodźcami i przymusowymi przesiedleńcami omawiany dokument podkreśla kolejno: konieczność poszanowania ludzkiej i chrześcijańskiej godności przybysza, miłość jako podstawową zasadę działania duszpasterskiego, solidarność z przybyszem i wspieranie go w jego egzystencjalnych potrzebach, wezwanie do międzynarodowej koniecznej i wielostronnej współpracy na rzecz uchodźców i wypędzonych celem niesienia przybyszom należnej pomocy duchowej i materialnej.

Podstawowe problemy uchodźców i innych przymusowo przesiedlonych omówione są w drugiej części instrukcji (art. 38-56). Obie dykasterie Stolicy Apostolskiej na tle globalizującego się świata bardzo szczegółowo omawiają dynamizujący się co dzień ogólnoświatowy problem uchodźstwa i przymusowych przesiedleń tak w skali międzykontynentalnej i międzypaństwowej, jak i wewnątrz poszczególnych wspólnot państwowych i etnicznych. Zwracają uwagę na sytuację egzystencjalną i prawną uchodźców oraz wynikającą stąd konieczność organizowania wydzielonych obozów dla uchodźców i azylantów, z dyscypliną zbliżoną do policyjnej, w których egzystują oni wraz ze swoimi rodzinami wiele lat, tracąc nadzieję na normalne życie oparte o rodzinę i zapracowany chleb. W tej części dokumentu omówione są również problemy, jakie obecność uchodźców niesie ze sobą dla społeczności ich przyjmującej, w tym szczególnie ważny problem podejmowania pracy i zajmowania miejsc pracy oraz problem integracji.

Wobec dokonanej specyfikacji grup tworzących współczesny fenomen uchodźstwa i przymusowego przesiedlenia, zapisy wybiegające w przyszłość znajdują się w trzeciej części instrukcji zatytułowanej: Prawa i obowiązki - patrzą w przyszłość (art. 57-81). Całość opiera się na zasadzie, że „w podejmowaniu problemów uchodźców i ubiegających się o azyl polityczny najważniejszym punktem odniesienia nie może być interes państwa czy bezpieczeństwo narodowe, lecz jedynie człowiek. Oznacza to pełne poszanowanie ludzkich praw, jak również zagwarantowanie tego, by została uszanowana potrzeba 
życia w społeczności, wynikająca z samej ludzkiej natury"15. Trzeba jednocześnie pamiętać, że kraje atrakcyjne dla ubiegających się o azyl winny podjąć „wspólną strategię, według której kraje pierwszego przybycia nie musiałyby ponosić całego ciężaru tego problemu"16.

Instrukcja Przyjęcie Chrystusa wskazując na obowiązki przybyszów, podkreśla: „uchodźcy i ubiegający się o azyl mają obowiązki wobec państwa przyjmującego, których muszą przestrzegać”17. „Od uchodźców należy wymagać, by odnosili się w sposób otwarty i pozytywny do społeczeństwa, które ich przyjmuje, oraz by byli gotowi gdy pojawi się taka możliwość - czynnie uczestniczyć w budowaniu razem zintegrowanej wspólnoty, która będzie wspólnym domem dla wszystkich"18.

Wśród praw uchodźców i przesiedlonych oraz ubiegających się o azyl omawiany dokument podkreśla prawo do ochrony i do niezawracania do kraju pochodzenia, oraz do takiego samego traktowania ich w kraju zatrzymania lub osiedlenia, jak obywateli tego kraju, który ich przyjmuje. Małżeństwo i rodzina winny „cieszyć się osobistą i rodzinną prywatnością oraz pracą zapewniającą godne utrzymanie i sprawiedliwe wynagrodzenie oraz miejscem zamieszkania godne człowieka”, a także adekwatną opiekę medyczną ${ }^{19}$. Dzieci i młodzież już od pierwszych chwil pobytu na emigracji winny mieć zapewnione prawo do wykształcenia ${ }^{20}$. Wśród praw przybyszów wymienionych w dokumencie i omówionych co do sposobu zachowania i przestrzegania, instrukcja Przyjęcie Chrystusa wskazała również na prawo do wolności religijnej ${ }^{21}$ oraz prawo do własnej duchowości i opieki duchowej zgodnej z wyznawaną religią ${ }^{22}$. W tej części instrukcja

\footnotetext{
${ }^{15}$ Przyjęcie Chrystusa, art. 58.

${ }^{16}$ TAMŻE, art. 65.

${ }^{17}$ TAMŻE, art. 59.

${ }^{18}$ Benedy K XVI, Orędzie na Światowy Dzień Migranta i Uchodźcy z 2007 roku.

${ }^{19}$ Przyjęcie Chrystusa, art. 61.

${ }^{20}$ TAMŻE.

${ }^{21}$ Por. Sobór Waty Kański II, Deklaracja o wolności religijnej Dignitas humanae, nr 2 .

${ }^{22}$ Przyjęcie Chrystusa, art. 62.
} 
odwołuje się do zapisów Karty Praw Rodziny oraz do dokumentu wpracowanego wspólnie przez Papieską Radę ds. Duszpasterstwa Migrantów i Podróżujących oraz Papieską Radę ds. Duszpasterstwa Służby Zdrowia pt.: Zdrowie reprodukcyjne uchodźców ${ }^{23}$. W art. 66 omawiana instrukcja przypomina, że „Stolica Apostolska (...) nie może powstrzymać się od wyrażenia swoich zastrzeżeń, gdy udzielana pomoc czy nawet środki stosowane mogą spowodować poważne szkody dla godności osoby ludzkiej i jej życia od chwili poczęcia aż do naturalnej śmierci, jak jest to uznawane przez rozum ludzki i wyrażana w moralności katolickiej"24.

Część czwarta instrukcji podejmuje tematykę specyfiki duszpasterstwa poszczególnych grup uchodźców i przymusowo przesiedlonych (art. 82-117). Treść tej części zostanie syntetycznie przedstawiona w kolejnym paragrafie niniejszego opracowania. Całość zwieńczona jest Zakończeniem (art. 118-124), które w kontekście lektury poszczególnych części przybiera charakter apelu. Zdaniem autorów instrukcji, „problem uchodźców i przesiedleńców może być rozwiązany tylko na drodze prawdziwego pojednania" ${ }^{25}$. Wobec narastającego problemu uchodźców każdy uczeń Jezusa Chrystusa „musi mieć odwage”, by nie odwracać od nich oczu, „ale pozwolić, by ich twarze przeniknęły do (...) serc, i przyjąć ich w (...) życiu”. By zrozumieć ich uczucia, obawy i lęki konieczne jest wsłuchanie się w ich nadzieję, tęsknotę i rozpacz ${ }^{26}$.

\section{Wskazania pastoralno-kanoniczne instrukcji}

Dla praktycznego zastosowania instrukcji Przyjąć Chrystusa w uchodźcach i przymusowo przesiedlonych w życiu Kościoła diecezjalnego i we wspólnocie parafialnej oraz misji cum cura animarum ważny jest jej ostatni rozdział, zatytułowany: Szczególne duszpasterstwo uchodźców i innych przymusowo przesiedlonych osób.

\footnotetext{
${ }^{23}$ Papieska Rada ds. SŁużby Zdrowia, Papieska Rada ds. Duszpasterstwa Migrantów i PodróżującyCh, Zdrowie reprodukcyjne uchodźców.

${ }^{24}$ Przyjęcie Chrystusa, art. 66.

25 TAMŻE, art. 122.

${ }^{26}$ TAMŻE, art. 120.
} 
3.1. Otwartość na przybyłych warunkiem godnego przyjęcia

Przyjęcie uchodźców i wypędzonych oraz ofiar handlu ludźmi we wspólnocie Kościoła diecezjalnego poprzez wewnątrz diecezjalne struktury duszpasterskie, a zwłaszcza poprzez wspólnotę parafialną oraz misję cum cura animarum i gościnność wobec przybyłych jest „podstawowym elementem posługi duszpasterskiej. (...) Przyjęcie takich osób nie jest tylko samym zadaniem, czy obowiązkiem, ale sposobem życia" ${ }^{27}$. Ofiarowana gościnność we wspólnocie parafialnej i w misji duszpasterskiej winna wynikać z troski o to, „by być wiernym Bogu, wsłuchiwać się w Jego głos w Piśmie Świętym i rozpoznawać go w ludziach, którzy nas otaczają"28. Przyjęcie drugiego oznacza nie tylko oferowanie mu bezpiecznego miejsca, „w którym znajdzie on pokrzepienie, szacunek, akceptację i przyjazną przystań”, ale również „uważne słuchanie i wzajemne dzielenie się historią życia”29.

Przyjazne przyjęcie uchodźców i wypędzonych szczególnie w pierwszym okresie wyraża się w wysiłku świadczenia nie tylko logistycznej i humanitarnej pomocy, ale na wsparciu moralnym i duchowym ${ }^{30}$. „Kościół musi się starać być obecnym wśród społeczności uchodźców, towarzyszyć im w trakcie ich ucieczki, podczas okresu wygania, powrotu do swojej wspólnoty lub wędrówki do kraju przesiedlenia"31. W procesie przyjmowania uchodźców należy uwzględnić specyfikę poszczególnych grup oraz ich przynależność religijną. Tak jak już wcześniej podkreślała instrukcja Erga migrantes $^{32}$ należy zwracać uwagę nie tylko na wiernych Kościoła rzymsko katolickiego, ale również na wiernych innych obrządków katolickich, na osoby należące do innych kościołów lub wspólnot chrześcijańskich, a także na wyznawców islamu i innych religii. „Przyjęcie uchodźców (...) jest istotnym wyrazem Ewangelii. Nowi

\footnotetext{
${ }^{27}$ TAMŻE, art. 82.

${ }^{28}$ TAMŻE, art. 83.

29 TAMŻE.

${ }^{30}$ TAMŻE, art. 85.

${ }^{31}$ Papieska Rada ds. Migrantów i Podróżujących, Duszpasterstwo uchodźców we wschodniej, centralnej i południowej Afryce, art. 23.

${ }^{32}$ EMCC nr 49-68.
} 
przesiedleńcy z niechrześcijańskiej albo areligijnej kultury są uprzywilejowanymi adresatami ewangelizacji, jako nowi ubodzy, do których jest skierowane świadectwo Ewangelii”" ${ }^{33}$. Wspólnota przyjmująca winna być świadoma, że przybyli przynieśli ze sobą wielki potencjał ewangelizacyjny, który w miejscu zatrzymania czy osiedlenia może wydać pożądane ewangelicznie owoce. Zadaniem przyjmujących jest dostrzec ten potencjał, uruchomić i wykorzystać go dla dobra tak przybyłych, jak i ich przyjmujących. Przyjmujący uchodźców i przesiedlonych powinni być „przygotowani i szczególnie wrażliwi pod tym względem" 34 .

\subsection{Konieczność duszpasterskich rozwiązań}

Wspólnocie parafialnej oraz istniejącej już misji cum cura animarum uchodźcy i przesiedleni dają możliwość przeżywania na nowo swojego wspólnotowego powołania, by jak nauczał Jan Paweł II, stawać się domem gościnnie otwartym na przybyszów ${ }^{35}$. Na terenie diecezji troska o ludzi w drodze „musi być widoczna zarówno w parafii personalnej, jak i terytorialnej" oraz w innych strukturach duszpasterskich ${ }^{36}$. Winna być podejmowana przez wspólnoty życia konsekrowanego, organizacje charytatywne, ruchy kościelne oraz specjalne powstające wspólnoty wiernych, angażujące się na rzecz dobra uchodźców i przymusowo przesiedlanych ${ }^{37}$. Pomimo płynności i tymczasowości właściwej migracjom człowieka, w tym uchodźców i przesiedleńców, szeroko definiowana troska o ich dobro winna opierać się o właściwe struktury. „Jeśli okaże się konieczne, powinny

\footnotetext{
${ }^{33}$ Przyjecie Chrystusa, art. 110.

${ }^{34}$ TAMŻE, art. 87.

${ }^{35}$ Jan PaweŁ II, Orędzie na Światowy Dzień Migranta i Uchodźcy z 1999 r.: „Misja właściwa każdej wspólnocie parafialnej oraz jej znaczenie w społeczeństwie wskazuje na doniosłą rolę, jaką odgrywa parafia w nawiązywaniu kontaktów z cudzoziemcami, w usuwaniu podziałów między ochrzczonymi, wychowywanymi w różnych kulturach, w dialogu z wyznawcami innych religii. Dla wspólnoty parafialnej nie jest to uboczna działalność, ale wpisana w jej instytucjonalne zadanie”.

${ }^{36}$ Przyjęcie Chrystusa, art. 89.

${ }^{37}$ TAMŻE.
} 
zostać powołane krajowe lub diecezjalne struktury duszpasterskie"38. Wskazane jest również poszukiwanie i powoływanie rozwiązań parafialnych, służących dobru przybyłych, nawet wówczas, gdy nie są katolikami czy chrześcijanami.

Tam gdzie wydaje się to konieczne, dla dobra duchowego uchodźców i wypędzonych można erygować parafie personalne, misje cum cura animarum lub kapelanie ${ }^{39}$. Jeśli przybyłych wiernych danej narodowości, obrządku lub języka jest zbyt mało na erygowanie wskazanych struktur duszpasterskich, „mogą być oni dołączeni do najbliższej parafii terytorialnej jako członkowie pozaterytorialni (outstationis) lub do misji duszpasterskiej" ${ }^{40}$. W kontekście budowania struktur apostolatu uchodźców i wypędzonych ważne wciąż pozostaje wskazanie Erga migrantes: „w każdym przypadku, kiedy trudne lub niemożliwe okaże się kanoniczne erygowanie (...) stabilnych struktur duszpasterskich, to nienaruszony pozostaje obowiązek opieki duszpasterskiej nad imigrantami katolikami w taki sposób, jaki po uwzględnieniu cech charakterystycznych dla ich sytuacji zostanie uznany za najbardziej skuteczny, nawet bez specyficznych instytucji kanonicznych”. Postawa ta znajduje swoje uzasadnienie w dalszej części tego samego artykułu EMCC: „nieformalna, a może nawet spontanicznie krystalizująca się (struktura) zasługuje na to, by ją rozwijać i uznać, (...), pomijając liczebność tych, do których jest adresowana, także dlatego, aby nie pozostawić miejsca na improwizację i dla osamotnionych i nieodpowiedzialnych duszpasterzy, czy nawet sekt"41.

3.3. Odpowiedzialność za duszpasterstwo uchodźców i wypędzonych

Zgodnie ze wskazaniami Kodeksu Prawa Kanonicznego, biskup ordynariusz diecezji jest odpowiedzialny za przyjęcie i otoczenie

\footnotetext{
38 TAMŻE.

${ }^{39}$ TAMŻE, art. 91; por. EMCC 91.

${ }^{40}$ Przyjęcie Chrystusa, art. 92.

${ }^{41}$ EMCC 92.
} 
właściwą oraz konieczną opieką uchodźców i przymusowo wysiedlonych, w tym za przyjęcie ofiar handlu ludźmi, wykorzystanych seksualnie, zmuszanych do pracy i za osoby przemycone ${ }^{42}$. „Strukturze episkopalnej Kościoła odpowiada fakt, że w kościołach partykularnych biskupi, jako następcy Apostołów, ponoszą jako pierwsi odpowiedzialność za realizację, także dziś, programu wskazanego w dziejach Apostolskich (Dz 2,42 44). Kościół jest Rodziną Bożą, powinien być dziś jak wczoraj, miejscem wzajemnej pomocy i równocześnie miejscem gotowości do służenia wszystkim potrzebującym, nawet tym, którzy pozostają poza nim"43.

Szczególna rola w duszpasterstwie uchodźców i przymusowo wypędzonych, którzy osadzeni są w specjalnych obozach, czy to poza miastami, czy w granicach miast, osiedli i wiosek, przypada współpracującym z biskupem diecezjalnym kapelanom - księżom diecezjalnym i zakonnym. Winni oni być wspierani przez siostry i braci zakonnych. Zadania duszpasterskie przed jakimi stają są trudne i wymagające. Wymagają specjalnego przygotowania ${ }^{44}$, co powinno być brane pod uwagę w momencie doboru i nominacji poszczególnych osób do tak specyficznego apostolatu ${ }^{45}$.

Instrukcja zauważa, że celem zaradzenia potrzebom przybyłych uchodźców i wypędzonych można wrócić do wskazanego przez Pawła VI w 1978 r. w liście apostolskim Chiesa e mobilità umana projektu „Duszpasterza bez granic”: „Opieka duszpasterska, której wymagają ludzie w drodze, jest duszpasterstwem, że tak powiem (...) bez granic. Odpowiednie środki można znaleźć tylko dzięki współpracy i solidarności pomiędzy zaangażowanymi Kościołami”46.

${ }^{42} \mathrm{KPK}$, kan. 383 par. $1-4$.

${ }^{43}$ DCE, nr 32.

${ }^{44}$ Przyjęcie Chrystusa, art. 97 i 99.

${ }^{45}$ TAMŻE, art. 90.

${ }^{46}$ PAWEŁ VI, List apostolski Chiesa e mobilità umana, art. 26. 
3.4. Obecność wiernych świeckich w pastoralnej posłudze uchodźcom i przymusowo przesiedlonym

W trosce o dobro duchowe uchodźców i wypędzonych ważna rola przypada wiernym świeckim. Szybko zmieniająca się sytuacja społeczno-kulturalna, dynamika zjawiska wypędzeń i przesiedleń, powodowana często toczącymi się wojnami i wielką niesprawiedliwością społeczną, w sposób naturalny wymaga wieloaspektowej, natychmiastowej opieki nad poszczególnymi kategoriami uchodźców. Zadaniu temu mogą sprostać przygotowani wierni świeccy. Oni to w łączności z Kościołem i w jego imieniu służą przybyszom od pierwszych dni pobytu na emigracji nie tylko wsparciem materialnym i organizacyjnym, ale również pomocą medyczną i prawną. Wierni świeccy ,inspirowani Pismem Świętym, Tradycją i Magisterium Kościoła, będą wrażliwi na trudną sytuację (...) szczególnie osób znajdujących się w potrzebie, okazując im miłość i niosąc ulgę w cierpieniu" ${ }^{47}$. Swoją postawą wynikającą ze sposobu świadectwa o Jezusie Chrystusie winni wskazywać przybyłym uchodźcom i wypędzonym ich prawa w nowym miejscu zatrzymania i osiedlenia, a także obowiązki wobec wspólnoty przyjmującej. Swoją działalnością będą reagowali na potrzeby przybyłych oraz przeciwdziałali dyskryminacji, ksenofobii i rasizmowi. Oni też mogą włączyć się w budowanie polityki bezpieczeństwa i ochrony praw uchodźców i wypędzonych ${ }^{48}$.

W ramach kanonicznych możliwości wierni świeccy mogą również angażować się w pomoc duszpasterzom migrantów i uchodźców. Mogą włączać się w sprawowanie czynności liturgicznych, aktów pobożności ludowej oraz w katechezy, w których biorą udział przybysze, a także brać udział w przygotowaniu ich do podejmowania właściwych im czynności i liturgicznych i katechetycznych ${ }^{49}$.

\footnotetext{
${ }^{47}$ Przyjęcie Chrystusa, art. 107.

48 TAMŻE, art. 108.

${ }^{49}$ TAMżE, art. 109; por. W. NeCEL, dz. cyt., s. 219-222.
} 
3.5. Konieczność współpracy z Kościołem a quo uchodźców i wypędzonych

Dla wieloaspektowej posługi i owocnego apostolatu uchodźców i wypędzonych, zgodnie ze wskazaniami Erga migrantes ${ }^{50}$, konieczna jest współpraca ich Kościoła macierzystego z Kościołem przyjmującym. „Oba Kościoły lokalne są wezwane do tego, aby utrzymać swoją specyficzną odpowiedzialność duszpasterską w duchu aktywnej i praktycznie wyrażonej komunii” ${ }^{51}$. Kościół macierzysty w omawianej instrukcji przynaglany jest do tego, by pozostawać w kontakcie ze swoimi wiernymi, „którzy z jakiegokolwiek powodu przenieśli się gdzie indziej”. Natomiast Kościół przyjmujący powinien podjąć kanonicznie wyznaczone obowiązki duszpasterskie względem przybyłych i osiedlających się na jego terenie ${ }^{52}$.

Instrukcja Przyjąć Chrystusa nawiązuje do wskazań Erga migrantes i podkreśla konieczność powołania zarówno w Kościele macierzystym jak i w Kościele przyjmującym Komisji Episkopatu ds. Duszpasterstwa Migrantów, które we współpracy ze sobą otoczą migrujących właściwą opieką duszpasterską i będą troszczyły się o przestrzeganie praw zarówno uchodźców jak i ich przyjmujących oraz w duchu Ewangelii będą artykułowały ich wzajemne obowiązki. Tam, gdzie „na chwilę obecną nie można takiej Komisji ustanowić, zaleca się, aby został powołany delegat Episkopatu ds. tego szczególnego duszpasterstwa" 53 .

\section{Zakończenie}

Przedstawiona instrukcja Papieskiej Rady ds. Duszpasterstwa Migrantów i Podróżujących oraz Papieskiej Rady Cor Unum wpisuje się w wielowiekową tradycję duszpasterskiej troski Kościoła o szczególną kategorię migrantów, jakimi są uchodźcy i przymusowo

\footnotetext{
${ }^{50}$ EMCC art. 16.

${ }^{51}$ Przyjęcie Chrystusa, art. 93; por. EMCC art. 16; W. NeCEL, Biskup a quo wobec emigrujących diecezjan, Poznań 2015, s. 12-21.

${ }^{52}$ Przyjęcie Chrystusa, art. 93; por. KPK, kan. 107 par. 1-3.

${ }^{53}$ Przyjęcie Chrystusa, art. 94.
} 
wysiedleni. Autorzy instrukcji obejmują tą kategorią także bezpaństwowców, ubiegających się o azyl polityczny, ofiary handlu ludźmi, w tym szczególnie dzieci i kobiety, ofiary pracy przymusowej oraz dzieci-żołnierzy.

Instrukcja Przyjęcie Chrystusa jest przede wszystkim świadectwem Kościoła, że wobec ogromu cierpienia wszystkich kategorii uchodźców i wypędzonych, tak w przeszłości jak i dzisiaj, nie może on milczeć. Każdy z przybyszów nosi w sobie „słuszne pragnienie szczęścia" ${ }^{4}$. Dlatego też wobec współczesnego zjawiska wypędzeń i przesiedleń, Kościół powszechny, Kościoły lokalne oraz wspólnoty parafialne, a także poszczególni wierni, winni wsłuchiwać się w ich nadzieje i rozpacze i zrozumieć ich uczucia oraz włączyć się w wieloraką pomoc ustrukturyzowaną w instrukcji. Ponadto wszyscy wierni Kościoła rzymsko katolickiego przesłaniem instrukcji Przyjęcie Chrystusa „mogą czuć się zachęceni do niestrudzonego działania, aby ustały wszelkie podziały i niezgoda. Pomoże to zbudować cywilizację prawdy i miłości w duchu solidarności między narodami na całym świecie" 55 .

Instrukcja Przyjęcie Chrystusa przekazana wszystkim zatroskanym o dobro duchowe uchodźców i przymusowo przesiedlonych przypomina wreszcie, że wciąż aktualne jest przesłanie Jana XXIII: „każdy człowiek ma prawo do życia, nienaruszalności ciała, do posiadania środków potrzebnych do zapewnienie sobie odpowiedniego poziomu życia, do których należy zaliczyć przede wszystkim żywność, odzież, mieszkanie, wypoczynek, opiekę zdrowotną oraz niezbędne świadczenia ze strony władz na rzecz jednostki"56.

\section{Adoption of Christ in refugees. Pastoral-canonical guidelines}

On the ground of the Erga Migrantes Caritas Christi 2004 instruction, the situation of refugees and expellees requires not only new analyzes and

\footnotetext{
${ }^{54}$ TAmŻE, art. 119; por. BenEdy KT XVI, Adhortacja Sacramentum caritatis, nr. 90.

${ }^{55}$ Przyjęcie Chrystusa, art. 121.

${ }^{56}$ JAN XXIII, Encyklika Pacem in terris, nr I,2.
} 
defining their position in the Universal and diocese Churches, but due to the dynamics of the migration phenomenon it is repeatedly necessary to update the pastoral tasks towards these categories of migrants. Political and social unrest in the first two decades of the twenty-first century was a catalyst for the development of the Apostolic See statement: Adoption of Christ in the refugees and forcibly expelled.

SŁOWA KLUCZOWE: migrant; uchodźca; wypędzony; bezpaństwowcy; ofiary handlu ludźmi; ofiary wykorzystane seksualnie z racji migracji; dzieci - migranci; troska Kościoła; Stolica Apostolska

KEY WORDS: migrant; refugee; expelled; stateless persons; victims of trafficking; victims sexually abused because of migration; children - migrants; care of the Church; the Apostolic See

\section{Nota o Autorze:}

Ks. DR HAB. WOJCIECH NECEL SCHR, PROF. UKSW - profesor nadzwyczajny na Wydziale Prawa Kanonicznego UKSW w Warszawie, kierownik zakładu Historii Źródeł i Literatury Prawa Kanonicznego w katedrze Historii Prawa Kanonicznego. 